\title{
Liquid-liquid phase separation in organic particles containing one and two organic species: importance of the average $\mathrm{O}: \mathrm{C}$
}

\author{
Mijung Song ${ }^{1}$, Suhan Ham ${ }^{1}$, Ryan J. Andrews ${ }^{2}$, Yuan You ${ }^{2}$, and Allan K. Bertram ${ }^{2}$ \\ ${ }^{1}$ Department of Earth and Environmental Sciences, Chonbuk National University, Jeollabuk-do, Republic of Korea \\ ${ }^{2}$ Department of Chemistry, University of British Columbia, Vancouver, BC, V6T 1Z1, Canada
}

Correspondence: Allan K. Bertram (bertram@chem.ubc.ca)

Received: 26 April 2018 - Discussion started: 2 May 2018

Revised: 9 August 2018 - Accepted: 12 August 2018 - Published: 22 August 2018

\begin{abstract}
Recently, experimental studies have shown that liquid-liquid phase separation (LLPS) can occur in organic particles free of inorganic salts. Most of these studies used organic particles consisting of secondary organic materials generated in environmental chambers. To gain additional insight into LLPS in organic particles free of inorganic salts, we studied LLPS in organic particles consisting of one and two commercially available organic species. For particles containing one organic species, three out of the six particle types investigated underwent LLPS. In these cases, LLPS was observed when the $\mathrm{O}: \mathrm{C}$ was $\leq 0.44$ (but not always) and the relative humidity ( $\mathrm{RH})$ was between $\sim 97 \%$ and $\sim 100 \%$. The mechanism of phase separation was likely nucleation and growth. For particles containing two organic species, 13 out of the 15 particle types investigated underwent LLPS. In these cases, LLPS was observed when the $\mathrm{O}: \mathrm{C}$ was $\leq 0.58$ (but not always) and mostly when the RH was between $\sim 90 \% \mathrm{RH}$ and $\sim 100 \% \mathrm{RH}$. The mechanism of phase separation was likely spinodal decomposition. In almost all cases when LLPS was observed (for both onecomponent and two-component particles), the highest $\mathrm{RH}$ at which two liquids was observed was $100 \pm 2.0 \%$, which has important implications for the cloud condensation nuclei $(\mathrm{CCN})$ properties of these particles. These combined results provide additional evidence that LLPS needs to be considered when predicting the $\mathrm{CCN}$ properties of organic particles in the atmosphere.
\end{abstract}

\section{Introduction}

Depending on location, organic materials comprise $20 \%$ $80 \%$ of the mass of submicrometer particles in the atmosphere (Zhang et al., 2007; Jimenez et al., 2009). While the exact chemical composition of this organic material is uncertain, measurements have shown that the oxygen-tocarbon elemental ratio $(\mathrm{O}: \mathrm{C})$ of this organic material ranges from roughly 0.2 to 1.0 (Zhang et al., 2007; Hallquist et al., 2009; Jimenez et al., 2009; Heald et al., 2010; Ng et al., 2010). Important organic functional groups include carboxylic acids, alcohols, polyols, sugars, aromatic compounds, amine groups, ethers, and esters (Decesari et al., 2006; Gilardoni et al., 2009; Hallquist et al., 2009). Organic particles can affect the Earth's energy budget directly by scattering and/or absorbing solar radiation and indirectly by serving as nuclei for cloud formation (Kanakidou et al., 2005; Hallquist et al., 2009; IPCC, 2013; Knopf et al., 2018). In addition, they can affect air quality and human health (Jang et al., 2006; Baltensperger et al., 2008) and provide a medium for multiphase reactions (George and Abbatt, 2010; Shiraiwa et al., 2011; Abbatt et al., 2012; Houle et al., 2015; Reed et al., 2017).

To predict the role of organic particles in the atmosphere, information on their possible phase transitions under atmospheric conditions is required (Hanel, 1976; Martin, 2000; Krieger et al., 2012; You et al., 2014; Freedman, 2017). One possible phase transition that particles can undergo as the relative humidity $(\mathrm{RH})$ varies in the atmosphere is liquidliquid phase separation (LLPS) (Pankow, 2003; Marcolli and Krieger, 2006; Ciobanu et al., 2009; Bertram et al., 2011; Krieger et al., 2012; Song et al., 2012a; Zuend and Seinfeld, 2012; Veghte et al., 2013; You et al., 2014; O’Brien et al., 
2015). During the last several years, researchers have focused on LLPS in particles containing both organic materials and inorganic salts. These studies have shown that these mixed particles can undergo LLPS when the $\mathrm{O}: \mathrm{C}$ of the organic species is less than $\sim 0.56$ but not greater than 0.80 (Bertram et al., 2011; Krieger et al., 2012; Smith et al., 2012; Song et al., 2012a; Schill and Tolbert, 2013; You et al., 2013, 2014). The effect of particle size, temperature, organic functional groups, $\mathrm{pH}$, and viscosity on LLPS in particles containing organic materials and inorganic salts has also been explored (Krieger et al., 2012; You et al., 2014; Losey et al., 2016; Freedman, 2017). The importance of LLPS in particles containing organic materials and inorganic salts for gas-particle partitioning (Zuend et al., 2010; Zuend and Seinfeld, 2012; Shiraiwa et al., 2013), hygroscopic properties (Hodas et al., 2015), optical properties (Fard et al., 2018), and cloud condensation nuclei (CCN) properties (Ovadnevaite et al., 2017) has also been investigated.

More recently, researchers have started to investigate LLPS in organic particles free of inorganic salts (RenbaumWolff et al., 2016; Rastak et al., 2017; Song et al., 2017). These studies have shown that LLPS can occur in particles containing secondary organic material (SOM) generated in environmental chambers when the $\mathrm{O}: \mathrm{C}$ of the organic material is less than roughly 0.5 . This work has also shown that LLPS occurs in SOM particles at RH values between approximately $95 \%$ and $100 \%$ with important implications for the CCN properties of these particles (Petters et al., 2006; Hodas et al., 2016; Rastak et al., 2017; Renbaum-Wolff et al., 2016; Ovadnevaite et al., 2017).

Most of the previous experimental studies that investigated LLPS in organic particles free of inorganic salts focused on SOM particles generated in environmental chambers (Renbaum-Wolff et al., 2016; Rastak et al., 2017; Song et al., 2017). In the following, we studied LLPS in organic particles containing one and two commercially available organic species. Studies were carried out as a function of the average $\mathrm{O}: \mathrm{C}$ of organic species to better constrain the $\mathrm{O}: \mathrm{C}$ range required for LLPS. These studies provide additional insight into LLPS in organic particles free of inorganic salts, and the results from these studies should be useful for testing thermodynamic models used to predict LLPS in atmospheric particles.

\section{Experiments}

\subsection{Materials}

Listed in Table 1 are the commercially available organic species studied as well as the relevant properties of these organic species. The $\mathrm{O}: \mathrm{C}$ of the organic species ranged from 0.29 to 0.75 . All organic components were purchased from Sigma-Aldrich with purities $\geq 98 \%$ and were used without further purification. In addition, all organic species studied are liquid at room temperature.

\subsection{Particle production}

Particles consisting of one organic species were generated by nebulizing the liquid organic species without the addition of a solvent. Particles consisting of two organics species were generated by first preparing a mixture of two liquid organics with the mass ratio of $1: 1$ and then nebulizing the mixture, again without the addition of a solvent. Based on visual observations, the mixtures of two liquid organics studied were homogeneous (i.e., one phase) prior to nebulization; hence a change in composition due to nebulizing the mixture was not expected. After nebulizing, the generated organic particles were deposited onto siliconized glass slides (Hampton Research, Canada). The nebulization and deposition process (followed by coagulation) resulted in organic particles suspended on the glass slides with lateral dimensions ranging from $\sim 30$ to $\sim 80 \mu \mathrm{m}$.

\subsection{Observations of LLPS using optical microscopy}

After depositing the organic particles on the glass slides, the glass slides were mounted in a temperature and $\mathrm{RH}$ controlled flow cell coupled to an optical microscope (Olympus BX43, 40× objective) (Parsons et al., 2004; Pant et al., 2006; Song et al., 2012a). The temperature of the flow cell was kept at $290 \pm 1 \mathrm{~K}$ in all experiments. RH in the flow cell was controlled by a continuous flow of humidified $\mathrm{N}_{2}$ gas. The total flow rate of the gas was fixed at $\sim 500 \mathrm{sccm}$. The RH was measured using a humidity and temperature sensor (Sensirion, Switzerland), which was calibrated by observing the deliquescence RH of pure potassium carbonate (44\% RH), sodium chloride (76\% RH), ammonium sulfate (80.5\% RH), and potassium nitrate $(93.5 \% \mathrm{RH})$ particles (Winston and Bates, 1960). The uncertainty of the RH was $\pm 2.0 \%$ after calibration.

At the beginning of an experiment to probe LLPS, the organic particles were equilibrated at $\sim 100 \% \mathrm{RH}$ for $\sim 10$ $15 \mathrm{~min}$. The RH was then reduced from $\sim 100 \%$ to $\sim 0 \%$, followed by an increase to $\sim 100 \% \mathrm{RH}$ if no LLPS was detected. If LLPS was detected, the RH was reduced from $\sim 100 \%$ to $\sim 5-10 \%$ lower than the RH at which the two liquid phases merged into one phase, followed by an increase to $\sim 100 \% \mathrm{RH}$. The RH was adjusted at a rate of $0.1 \% \mathrm{RH} \mathrm{min}^{-1}-0.5 \% \mathrm{RH} \mathrm{min}^{-1}$. During the experiments, optical images of several different particles were recorded every $1-10 \mathrm{~s}$ using a video camera with a CMOS (complementary metal-oxide-semiconductor) detector. 
Table 1. Organic species studied, as well as molecular formula, molecular structure, molecular weight, solubility in water, oxygen-to-carbon elemental ratios $(\mathrm{O}: \mathrm{C})$, and functional groups of the species studied. All organic species are liquid at room temperature.

\begin{tabular}{|c|c|c|c|c|c|c|}
\hline Compound & $\begin{array}{l}\text { Molecular } \\
\text { formula }\end{array}$ & $\begin{array}{l}\text { Molecular } \\
\text { structure }\end{array}$ & $\begin{array}{r}\text { Molecular } \\
\text { weight } \\
\left(\mathrm{g} \mathrm{mol}^{-1}\right)\end{array}$ & $\begin{array}{r}\text { Solubility in } \\
\text { water at } 298 \mathrm{~K} \\
\left(\mathrm{~g} \mathrm{~L}^{-1}\right)\end{array}$ & $\mathrm{O}: \mathrm{C}$ & $\begin{array}{l}\text { Functional } \\
\text { group }\end{array}$ \\
\hline Diethyl sebacate & $\mathrm{C}_{14} \mathrm{H}_{26} \mathrm{O}_{4}$ & & 258 & $\begin{array}{r}0.08 \\
(\text { at } 293 \mathrm{~K})^{\mathrm{a}}\end{array}$ & 0.29 & Ester \\
\hline Poly (propylene glycol) & $\mathrm{C}_{3 n} \mathrm{H}_{6 n+2} \mathrm{O}_{n+1}$ & & 425 & $>10^{\mathrm{a}}$ & 0.38 & Alcohol, ether \\
\hline Glyceryl tributyrate & $\mathrm{C}_{15} \mathrm{H}_{26} \mathrm{O}_{6}$ & & 302 & $0.02^{\mathrm{b}}$ & 0.40 & Ester \\
\hline $\begin{array}{l}\text { Suberic acid monomethyl } \\
\text { ester }\end{array}$ & $\mathrm{C}_{9} \mathrm{H}_{16} \mathrm{O}_{4}$ & & 188 & $2.1^{\mathrm{b}}$ & 0.44 & $\begin{array}{l}\text { Carboxylic acid, } \\
\text { ester }\end{array}$ \\
\hline Polyethylene glycol-400 & $\mathrm{C}_{2 n} \mathrm{H}_{4 n+2} \mathrm{O}_{n+1}$ & & 400 & $>10^{\mathrm{c}}$ & 0.56 & Alcohol, ether \\
\hline Diethyl L-tartrate & $\mathrm{C}_{8} \mathrm{H}_{14} \mathrm{O}_{6}$ & & 206 & $71.9^{\mathrm{b}}$ & 0.75 & Alcohol, ester \\
\hline
\end{tabular}

\section{Results and discussion}

\subsection{Liquid-liquid phase separation in particles containing one organic species}

At $290 \pm 1 \mathrm{~K}$, humidity cycles were performed with six different types of particles containing one organic species. Three out of the six particle types studied (particles containing diethyl sebacate, glyceryl tributyrate, and suberic acid monomethyl ester) underwent LLPS as RH was cycled from $\sim 100 \%$ to lower values and back to $\sim 100 \%$. The results did not depend on particle diameter although only a narrow range of diameters $(\sim 30$ to $\sim 80 \mu \mathrm{m})$ was investigated. Shown in Fig. 1 and Movies S1-S3 in the Supplement are images and movies as the RH was decreased for the three particles types that underwent LLPS. At $\sim 100 \% \mathrm{RH}$, diethyl sebacate particles (Fig. 1a) had a core-shell morphology. As RH decreased from $\sim 100 \%$, the amount of the inner phase decreased and eventually the two liquid phases were merged into one liquid phase at $99 \% \mathrm{RH}-97 \% \mathrm{RH}$. We assume that the outer phase was an organic-rich phase and the inner phase was a water-rich phase since the amount of the inner phase decreased as the RH decreased. This assumption is also consistent with the surface tensions of organics and water, spreading coefficient theory, aerosol optical tweezers experiments, and X-ray microscopy measurements (Jasper, 1972; Kwamena et al., 2010; Reid et al., 2011; Song et al., 2013; O'Brien et al., 2015; Gorkowski et al., 2016, 2017). At $\sim 100 \%$ RH, glyceryl tributyrate and suberic acid monomethyl ester particles (Fig. 1b-c) had inclusions of a water-rich phase suspended in an organic-rich phase. As RH decreased from $\sim 100 \%$, the amount of the water-rich phase decreased and eventually the two liquid phases were merged into one liquid phase at $99-97 \%$ RH. We assume the inclusions were a water-rich phase since they decreased in size as the RH decreased.

Figure 2 and Movies S4-S6 show the same particles as those shown in Fig. 1 and Movies S1-S3 but with increasing RH. In these cases, the particles remain as a single phase up to $98 \%$ RH-99\% RH (Fig. 2). The light-colored circle in the center of each particle in the figure is due to the optical effect of light scattering (Bertram et al., 2011). Above $\sim 99 \% \mathrm{RH}$, two liquid phases are observed with the waterrich phase forming inclusions suspended in the organic-rich phase. As the RH increased, the water-rich phase continued to grow. Based on the movies, the mechanism for the formation of the water-rich phase is likely nucleation and growth (Movies S4-S6) rather than spinodal decomposition. Nucleation and growth appeared to begin from the edge of the particles of diethyl sebacate and suberic acid monomethyl ester (Movies S4 and S6) while nucleation appeared to begin from the interior of the particles of glyceryl tributyrate (Movie S5).

In Table 2, the measured lower RH boundary for LLPS (LLPS ${ }_{\text {lower }}$ ) and measured upper RH boundary for LLPS $\left(\right.$ LLPS $\left._{\text {upper }}\right)$ are reported. LLPS lower $_{\text {and }}$ LLPS $_{\text {upper }}$ represent the lowest and highest $\mathrm{RH}$ at which two liquid phases were observed in the experiments. Table 2 shows that LLPS $_{\text {lower }}$ and LLPS $S_{\text {upper }}$ were the same (within the uncertainties of the measurements) for both the increasing $\mathrm{RH}$ and decreasing RH experiments. This suggests that the kinetic barrier to 
Table 2. Lower RH boundary for LLPS (LLPS lower $_{\text {) and upper RH boundary for LLPS (LLPS }}$ upper) for particles containing one organic species. LLPS Uncertainties represent $2 \sigma$ of multiple measurements and the uncertainty from the calibration. "No LLPS" indicates that only one phase was observed for the full range of relative humidity explored ( $\sim 0$ to $100 \% \mathrm{RH})$.

\begin{tabular}{lcc|cc}
\hline & \multicolumn{2}{c|}{ Increasing RH } & Decreasing RH \\
\hline Compounds & LLPS $_{\text {lower }}$ & LLPS $_{\text {upper }}$ & LLPS $_{\text {lower }}$ & LLPS $_{\text {upper }}$ \\
Diethyl sebacate $(\mathrm{O}: \mathrm{C}=0.29)$ & $99.0 \pm 2.8$ & $100 \pm 2.0$ & $97.7 \pm 3.1$ & $100 \pm 2.0$ \\
Poly (propylene glycol $)(\mathrm{O}: \mathrm{C}=0.38)$ & \multicolumn{2}{c|}{ No LLPS } & \multicolumn{2}{c}{ No LLPS } \\
Glyceryl tributyrate $(\mathrm{O}: \mathrm{C}=0.40)$ & $98.8 \pm 2.2$ & $100 \pm 2.0$ & $97.9 \pm 2.3$ & $100 \pm 2.0$ \\
Suberic acid monomethyl ester $(\mathrm{O}: \mathrm{C}=0.44)$ & $99.2 \pm 2.1$ & $100 \pm 2.0$ & $99.2 \pm 2.2$ & $100 \pm 2.0$ \\
Polyethylene glycol-400 $(\mathrm{O}: \mathrm{C}=0.56)$ & \multicolumn{2}{c|}{ No LLPS } & No LLPS \\
Diethyl L-tartrate $(\mathrm{O}: \mathrm{C}=0.75)$ & \multicolumn{2}{c|}{ No LLPS } & No LLPS \\
\hline
\end{tabular}

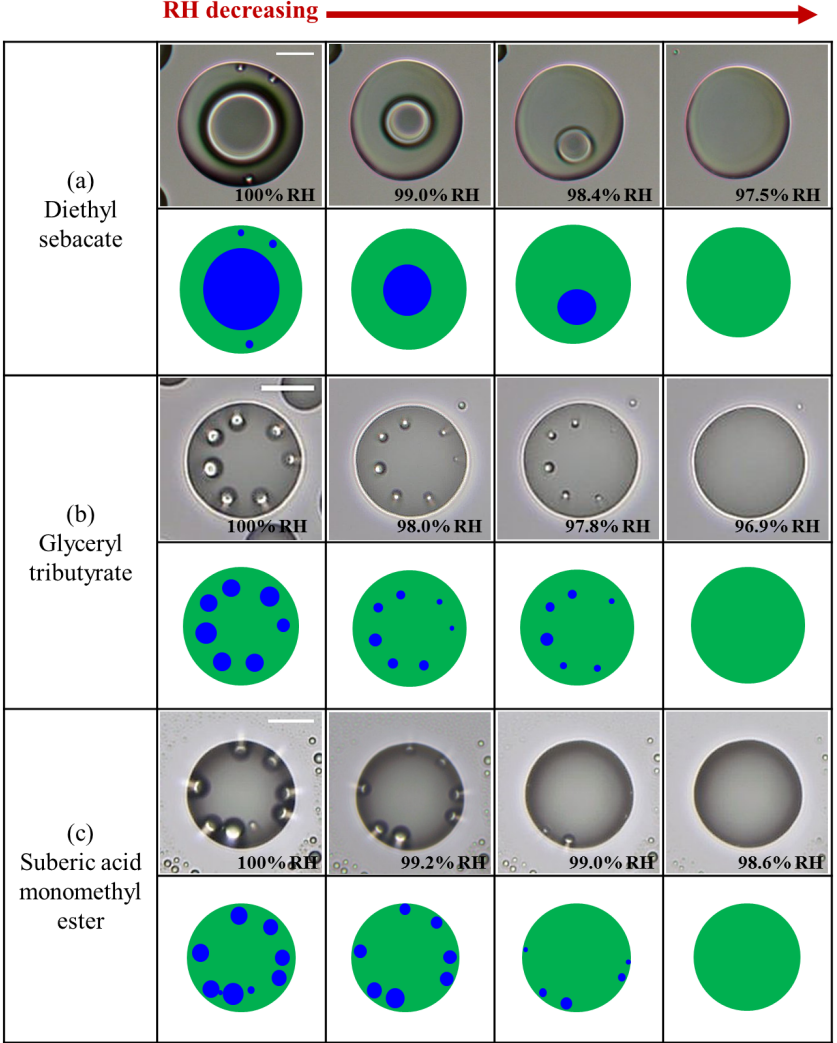

Figure 1. Optical images of single particles consisting of one organic species with decreasing RH: (a) diethyl sebacate particles, (b) glyceryl tributyrate particles, and (c) suberic acid monomethyl ester particles. The "streaks" extending from the inclusions to the edge of the particles in (b) and (c) are an optical effect. Illustrations are presented below the images. Green: organic-rich phase. Blue: water-rich phase. The scale bar is $20 \mu \mathrm{m}$.

LLPS in these experiments is small. According to the Gibbs phase rule, two liquid phases coexist in equilibrium with the gas phase only at a single RH. Within experimental uncertainty, our results are consistent with this rule. Table 2 also illustrates that LLPS can occur (but does not always do so)

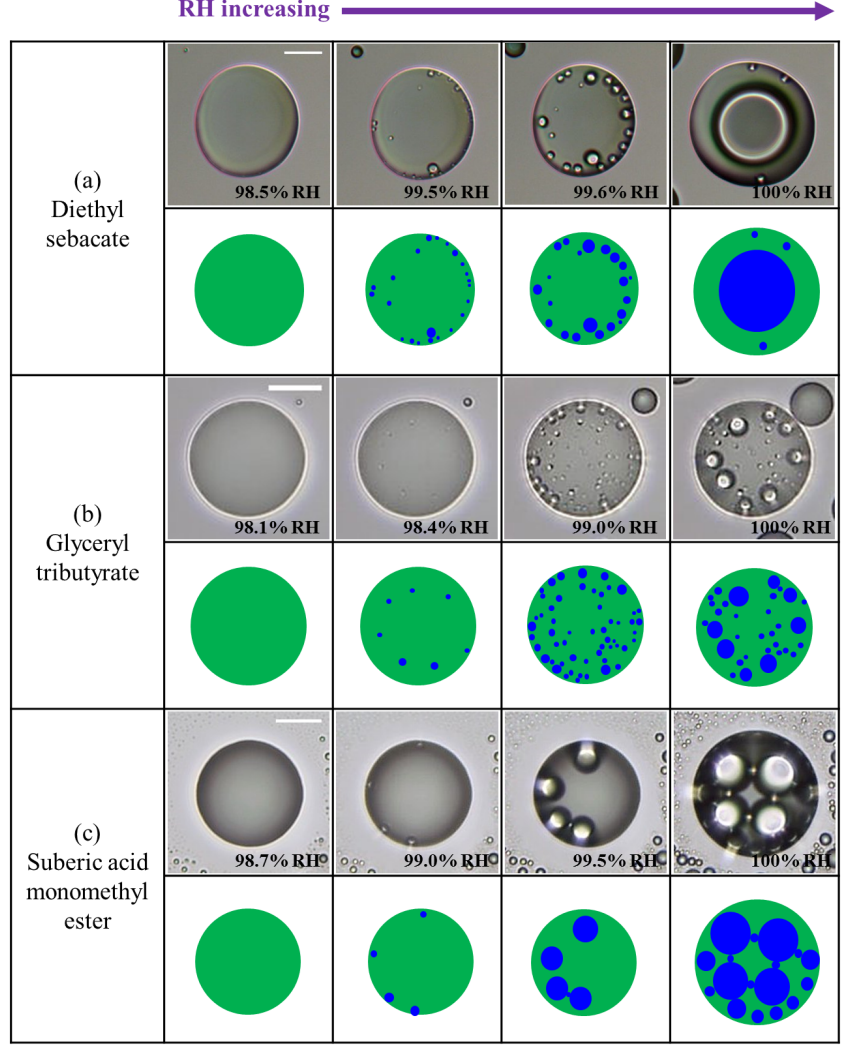

Figure 2. Optical images of single particles consisting of one organic species with increasing RH: (a) diethyl sebacate particles, (b) glyceryl tributyrate particles, and (c) suberic acid monomethyl ester particles. The particles are the same ones as shown in Fig. 1 but for increasing RH. Illustrations are presented below the images. Green: organic-rich phase. Blue: water-rich phase. The scale bar is $20 \mu \mathrm{m}$.

in organic particles containing one organic species when the $\mathrm{O}: \mathrm{C}$ ratio is $\leq 0.44$. In addition to the $\mathrm{O}: \mathrm{C}$ ratio, the types of organic functional groups present in the molecules are also likely important for LLPS (Song et al., 2012b), since dif- 
ferent functional groups lead to different strengths of intermolecular forces with water.

\subsection{Liquid-liquid phase separation in particles containing two organic species}

Using combinations of the organic species shown in Table 1, we studied LLPS in particles containing two organic species. Of the 15 particle types investigated, 13 particle types underwent LLPS during humidity cycles. Shown in Fig. 3 and Movies S7-S9 are images of three of the particle types that underwent LLPS (glyceryl tributyrate/polyethylene glycol-400, diethyl sebacate/polyethylene glycol-400, and polypropylene glycol/polyethylene glycol-400) as RH decreased from $\sim 100 \%$. The three particle types shown consisted of two liquid phases over the largest RH range observed in our experiments. At $\sim 100 \% \mathrm{RH}$, glyceryl tributyrate/polyethylene glycol-400 particles (Fig. 3a) and diethyl sebacate/polyethylene glycol-400 particles (Fig. 3b) had a core-shell morphology, with the shell consisting of an organic-rich phase and the core consisting of a waterrich phase. As the RH decreased, the two liquid phases merged into one liquid phase (Fig. 3a-b and Movies S7-S8). The polypropylene glycerol/polyethylene glycol-400 particles (Fig. 3c) also underwent LLPS as the RH decreased, but their behavior was slightly different. At $\sim 100 \%$ RH, only a single phase was observed. As the RH decreased, a very thin outer shell was observed as well as inclusions in the core of the particle at $\sim 89 \% \mathrm{RH}$. The shell and inclusions were most likely an organic-rich phase. At $\sim 74 \%$ RH the two liquid phases merged into one (Fig. 3c and Movie S9).

Figure 4 and Movies S10-S12 correspond to the same particles as shown in Fig. 3 and Movies S7-S9 but for increasing $\mathrm{RH}$. At the lowest RH values studied, all three particle types consisted of a single organic-rich phase (Fig. $4 \mathrm{a}-\mathrm{c}$ ). As the RH increased, numerous small inclusions appeared throughout the particles. These small inclusions then coalesced resulting in a core-shell morphology. Based on the movies (Movies S10-S12), the mechanism of LLPS was likely spinodal decomposition, a phase transition that occurs without an energy barrier (Ciobanu et al., 2009; Song et al., 2013). LLPS in SOM particles produced from the ozonolysis of $\alpha$ pinene, limonene, and $\beta$-caryophyllene also appeared to occur by this mechanism (Renbaum-Wolff et al., 2016; Song et al., 2017).

In Table 3 the measured LLPS ${ }_{\text {lower }}$ and LLPS upper $_{\text {for par- }}$ ticles containing two organics are reported as a function of the average $\mathrm{O}: \mathrm{C}$ in the particles. Only results from the increasing RH experiments are shown. Within uncertainty, the same results were obtained for decreasing RH (Table S1 in the Supplement), indicating that a kinetic barrier to the LLPS in these experiments was small. The average $\mathrm{O}: \mathrm{C}$ values for particles containing two organic species were calculated using Eq. (S1) in the Supplement. The only particles containing two organics that did not undergo LLPS were particles con-

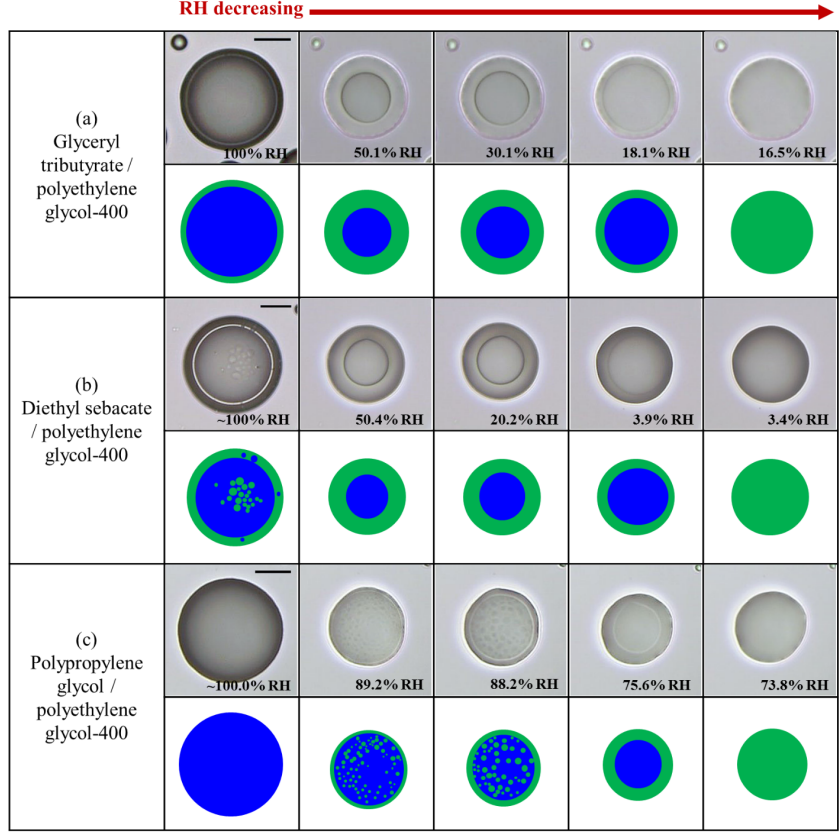

Figure 3. Optical images for particles consisting of two organic species for decreasing RH: (a) glyceryl tributyrate/polyethylene glycol-400, (b) diethyl sebacate/polyethylene glycol-400, and (c) poly(propylene glycol)/polyethylglycol-400. Illustrations are presented below the images for clarity. Green: organic-rich phase. Blue: water-rich phase. The scale bar is $20 \mu \mathrm{m}$.

sisting of propylene glycol/diethyl L-tartrate and polyethylene glycol-400/diethyl L-tartrate (Table 3). These two particles had the highest and third highest average $\mathrm{O}: \mathrm{C}$ values of all the two component particles investigated (Table 3 ). This is consistent with reported phase transitions in bulk solutions containing two organics and water (Ganbavale et al., 2015). To illustrate, in a bulk mixture of two organics and water with a low average $\mathrm{O}: \mathrm{C}$ value (e.g., a mixture of 1-butanol, 1-propanol, and water), two liquids can form (Ganbavale et al., 2015). On the other hand, in a bulk mixture of two organics and water with a high average $\mathrm{O}: \mathrm{C}$ value (e.g., a mixture of acetic acid, ethanol, and water), only a single liquid is observed (Ganbavale et al., 2015).

Table 3 illustrates that LLPS in particles containing two organics was mostly observed between $\sim 90 \% \mathrm{RH}$ and $~$ $100 \% \mathrm{RH}$. The exception to this was particles containing polyethylene glycol-400 mixed with glyceryl tributyrate, diethyl sebacate, or polyprophylene glycol. In these three cases two liquid phases were observed over a much wider range and in one case from $\sim 5 \%$ to $\sim 100 \%$ RH. Table 3 also illustrates that when LLPS occurred in particles containing

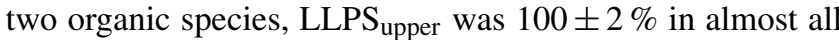
cases. This is important as it suggests that these organic particles can have an organic-rich shell at high $\mathrm{RH}$, which could lower the surface tension and influence the $\mathrm{CCN}$ properties of the particles (Petters et al., 2006; Hodas et al., 2016; 


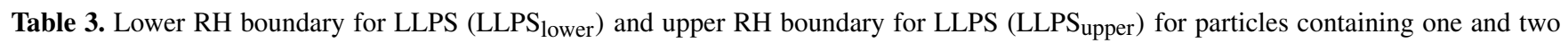
organic species. LLPS ${ }_{\text {lower }}$ and LLPS Uncertainties represent $2 \sigma$ of multiple measurements and the uncertainty from the calibration. "No LLPS" indicates that only one phase was observed for the full range of relative humidity $(\mathrm{RH})$ explored $(\sim 0$ to $100 \% \mathrm{RH})$. Only results are shown here for increasing $\mathrm{RH}$. For particles containing one organic species the $\mathrm{O}: \mathrm{C}$ of the organic is indicated in brackets. For particles containing two organics, the average $\mathrm{O}: \mathrm{C}$ of the particles is indicated in brackets.

\begin{tabular}{|c|c|c|c|c|c|c|}
\hline & $\begin{array}{l}\text { Diethyl } \\
\text { sebacate }\end{array}$ & $\begin{array}{l}\text { Propylene } \\
\text { glycol }\end{array}$ & $\begin{array}{l}\text { Glyceryl } \\
\text { tributyrate, }\end{array}$ & $\begin{array}{l}\text { Suberic acid } \\
\text { monomethyl } \\
\text { ester }\end{array}$ & $\begin{array}{l}\text { Polyethylene } \\
\text { glycol-400 }\end{array}$ & $\begin{array}{l}\text { Diethyl L- } \\
\text { tartrate }\end{array}$ \\
\hline $\begin{array}{l}\text { Diethyl } \\
\text { sebacate }\end{array}$ & $\begin{array}{l}\text { LLPS }_{\text {lower }}=99.0 \pm 2.8 \% \\
\text { LLPS }_{\text {upper }}=100 \pm 2.0 \% \\
(O: C=0.29)\end{array}$ & & & & & \\
\hline $\begin{array}{l}\text { Propylene } \\
\text { glycol }\end{array}$ & $\begin{array}{l}\text { LLPS }_{\text {lower }}=92.4 \pm 2.1 \% \\
\text { LLPS }_{\text {upper }}=100 \pm 2.0 \% \\
(O: C=0.33)\end{array}$ & $\begin{array}{l}\text { No LLPS } \\
(\mathrm{O}: \mathrm{C}=0.38)\end{array}$ & & & & \\
\hline $\begin{array}{l}\text { Glyceryl } \\
\text { tributyrate }\end{array}$ & $\begin{array}{l}\text { LLPS }_{\text {lower }}=96.3 \pm 4.3 \% \\
\mathrm{LLPS}_{\text {upper }}=100 \pm 2.0 \% \\
(\mathrm{O}: \mathrm{C}=0.34)\end{array}$ & $\begin{array}{l}\text { LLPS }_{\text {lower }}=93.8 \pm 2.3 \% \\
\text { LLPS }_{\text {upper }}=100 \pm 2.0 \% \\
(\mathrm{O}: \mathrm{C}=0.39)\end{array}$ & $\begin{array}{l}\text { LLPS }_{\text {lower }}=98.9 \pm 2.2 \% \\
\mathrm{LLPS}_{\text {upper }}=100 \pm 2.0 \% \\
(\mathrm{O}: \mathrm{C}=0.40)\end{array}$ & & & \\
\hline $\begin{array}{l}\text { Suberic acid } \\
\text { monomethyl } \\
\text { ester }\end{array}$ & $\begin{array}{l}\text { LLPS }_{\text {lower }}=97.4 \pm 3.1 \% \\
\text { LLPS }_{\text {upper }}=100 \pm 2.0 \% \\
(O: C=0.36)\end{array}$ & $\begin{array}{l}\text { LLPS }_{\text {lower }}=97.7 \pm 2.3 \% \\
\mathrm{LLPS}_{\text {upper }}=100 \pm 2.0 \% \\
(\mathrm{O}: \mathrm{C}=0.42)\end{array}$ & $\begin{array}{l}\text { LLPS }_{\text {lower }}=97.6 \pm 3.4 \% \\
\operatorname{LLPS}_{\text {upper }}=100 \pm 2.0 \% \\
(\mathrm{O}: \mathrm{C}=0.42)\end{array}$ & $\begin{array}{l}\text { LLPS }_{\text {lower }}=99.2 \pm 2.1 \% \\
\mathrm{LLPS}_{\text {upper }}=100 \pm 2.0 \% \\
(\mathrm{O}: \mathrm{C}=0.44)\end{array}$ & & \\
\hline $\begin{array}{l}\text { Polyethylene } \\
\text { glycol-400 }\end{array}$ & $\begin{array}{l}\text { LLPS }_{\text {lower }}=5.2 \pm 3.8 \% \\
\text { LLPS }_{\text {upper }}=100 \pm 2.0 \% \\
(O: C=0.39)\end{array}$ & $\begin{array}{l}\text { LLPS }_{\text {lower }}=73.9 \pm 2.5 \% \\
\mathrm{LLPS}_{\text {upper }}=89.9 \pm 3.0 \% \\
(\mathrm{O}: \mathrm{C}=0.47)\end{array}$ & $\begin{array}{l}\text { LLPS }_{\text {lower }}=16.0 \pm 2.3 \% \\
\text { LLPS }_{\text {upper }}=100 \pm 2.0 \% \\
(\mathrm{O}: \mathrm{C}=0.47)\end{array}$ & $\begin{array}{l}\text { LLPS }_{\text {lower }}=93.2 \pm 3.2 \% \\
\mathrm{LLPS}_{\text {upper }}=100 \pm 2.0 \% \\
(\mathrm{O}: \mathrm{C}=0.50)\end{array}$ & $\begin{array}{l}\text { No LLPS } \\
(\mathrm{O}: \mathrm{C}=0.56)\end{array}$ & \\
\hline $\begin{array}{l}\text { Diethyl L- } \\
\text { tartrate }\end{array}$ & $\begin{array}{l}\text { LLPS }_{\text {lower }}=92.8 \pm 3.4 \% \\
\text { LLPS }_{\text {upper }}=100 \pm 2.0 \% \\
(\mathrm{O}: \mathrm{C}=0.48)\end{array}$ & $\begin{array}{l}\text { No LLPS } \\
(\mathrm{O}: \mathrm{C}=0.56)\end{array}$ & $\begin{array}{l}\operatorname{LLPS}_{\text {lower }}=93.9 \pm 3.3 \% \\
\mathrm{LLPS}_{\text {upper }}=100 \pm 2.0 \% \\
(\mathrm{O}: \mathrm{C}=0.55)\end{array}$ & $\begin{array}{l}\text { LLPS }_{\text {lower }}=97.3 \pm 2.7 \% \\
\operatorname{LLPS}_{\text {upper }}=100 \pm 2.0 \% \\
(\mathrm{O}: \mathrm{C}=0.58)\end{array}$ & $\begin{array}{l}\text { No LLPS } \\
(\mathrm{O}: \mathrm{C}=0.68)\end{array}$ & $\begin{array}{l}\text { No LLPS } \\
(\mathrm{O}: \mathrm{C}=0.75)\end{array}$ \\
\hline
\end{tabular}

Renbaum-Wolff et al., 2016; Rastak et al., 2017; Ovadnevaite et al., 2017).

\subsection{Comparison between particles containing one organic species, two organic species, and secondary organic materials}

Shown in Fig. 5 are the lower and upper RH boundaries for LLPS (LLPS $_{\text {lower }}$ and LLPS $_{\text {upper }}$ ) as a function of the O:C for particles containing one organic species (Fig. 5a), particles containing two organic species (Fig. 5b), and particles consisting of SOM generated in environmental chambers (Fig. 5c). Results for particles consisting of SOM were taken from Renbaum-Wolff et al. (2016), Rastak et al. (2017), and Song et al. (2017). The O: $\mathrm{C}$ range of the SOM particles is based on previous studies (Heaton et al., 2007; Lambe et al., 2015; Li et al., 2015; Renbaum-Wolff et al., 2016; Rastak et al., 2017; Song et al., 2017).

Figure 5 suggests that LLPS in two-component organic particles (Fig. 5b) occurs over a wider range of average $\mathrm{O}: \mathrm{C}$ values than LLPS in one-component organic particles (Fig. 5a). In addition, LLPS in two-component organic particles occurs over a wider range of RH values than LLPS in one-component organic particles. Figure 5 also suggests that the average $\mathrm{O}: \mathrm{C}$ is an important factor (although not the only factor) in determining the occurrence of LLPS in organic particles. For particles containing one organic species, LLPS was observed when the $\mathrm{O}: \mathrm{C}$ was $\leq 0.44$ (but not in all cases); for particles containing two organic species, LLPS was observed when the $\mathrm{O}: \mathrm{C}$ was $\leq 0.58$ (but not in all cases); and for particles containing SOM, LLPS was observed when the $\mathrm{O}: \mathrm{C}$ was 0.44 . In Fig. 5, the $\mathrm{O}: \mathrm{C}$ range found in ambient organic aerosols is also shown (Zhang et al., 2007; Hallquist et al., 2009; Jimenez et al., 2009; Heald et al., 2010; $\mathrm{Ng}$ et al., 2010). Based on this range and the range over which LLPS was observed in one-component organic particles, two-component organic particles, and SOM particles, LLPS is likely a common feature of organic aerosols in the atmosphere.

In addition to the average $\mathrm{O}: \mathrm{C}$ and the types of functional groups, the spread in the $\mathrm{O}: \mathrm{C}$ values of the organic molecules with the same particles is likely important for LLPS. Additional studies are needed to isolate the effect of average $\mathrm{O}: \mathrm{C}$, functional groups, and spread in $\mathrm{O}: \mathrm{C}$ values on LLPS in organic particles.

Figure 5 also illustrates that where LLPS was observed, LLPS $_{\text {upper }}$ was $100 \pm 2.0 \%$ in almost all cases. In these cases, an organic-rich phase can form a shell around the particles and lower the surface tension of the particles at high $\mathrm{RH}$, with important consequences for the $\mathrm{CCN}$ properties of the organic particles (Petters et al. 2006; Hodas et al. 2016; Renbaum-Wolff et al., 2016; Rastak et al., 2017; Ovadnevaite et al., 2017). These combined results provide additional evidence that LLPS needs to be considered when predicting the $\mathrm{CCN}$ properties of organic particles in the atmosphere. 


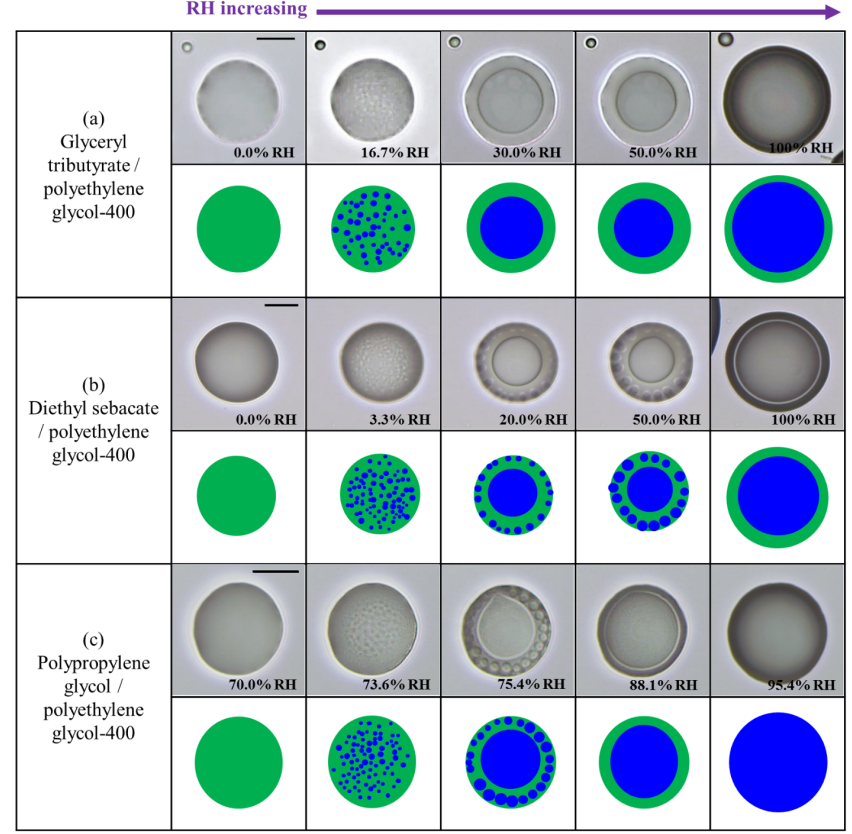

Figure 4. Optical images for particles consisting of two organic species for increasing RH: (a) glyceryl tributyrate/polyethylene glycol-400, (b) diethyl sebacate/ polyethylene glycol-400, and (c) poly(propylene glycol)/polyethylglycol-400. The particles are the same as shown in Fig. 3 but for increasing RH. Illustrations are presented below the images for clarity. Green: organic-rich phase. Blue: water-rich phase. The scale bar is $20 \mu \mathrm{m}$.

\section{Summary and conclusions}

We investigated LLPS at $290 \pm 1 \mathrm{~K}$ in organic particles containing one and two organic species free of inorganic salts. For organic particles containing one organic species, three of the six different particle types studied underwent LLPS. For the three cases where LLPS was observed, particles separated when the $\mathrm{O}: \mathrm{C}$ was $\leq 0.44$ (but not in all cases) and the $\mathrm{RH}$ was close to $\sim 100 \%$. The mechanism for LLPS in these particles was likely nucleation and growth.

Using combinations of the organic species, we also investigated LLPS in particles containing two organic species. Thirteen out of the fifteen particle types investigated underwent LLPS, and LLPS was observed when the $\mathrm{O}: \mathrm{C}$ was $\leq 0.58$ (but not in all cases). The mechanism of phase separation was likely spinodal decomposition. In these cases, LLPS was observed between $\sim 90 \% \mathrm{RH}$ and $\sim 100 \% \mathrm{RH}$, except for three cases in which LLPS was observed over a much wider range of $\mathrm{RH}(5 \%$ to $100 \%)$.

Since the $\mathrm{O}: \mathrm{C}$ of organic particles in the atmosphere ranges from $\sim 0.2$ to $\sim 1.0$, these results provide additional support for the suggestion that LLPS can occur in organic particles in the atmosphere. In addition to the average $\mathrm{O}: \mathrm{C}$, organic functional groups and the spread in the $\mathrm{O}: \mathrm{C}$ values within organic particles are likely important for LLPS. Ad-

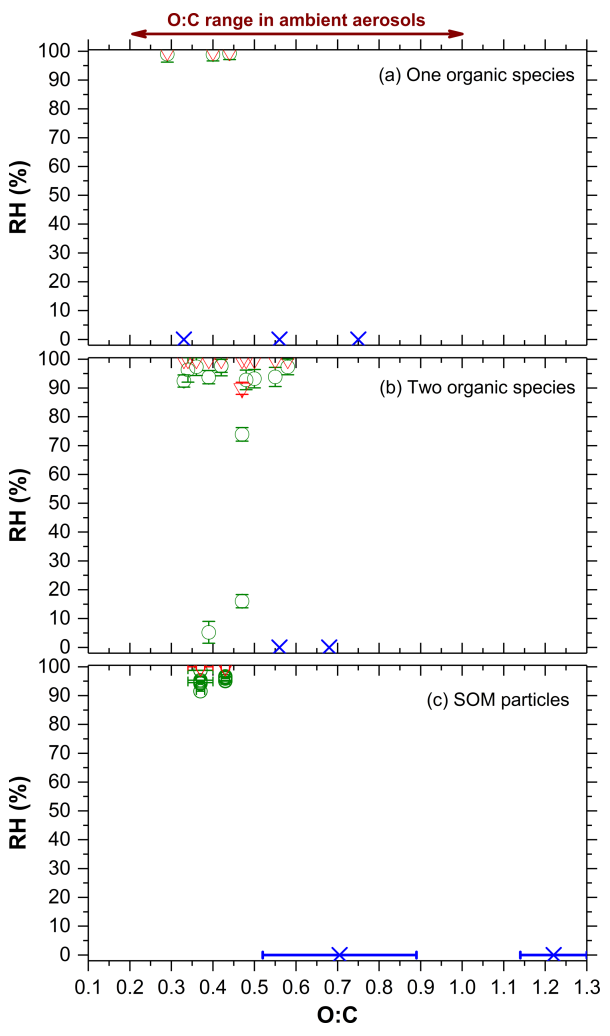

Figure 5. Lower and upper RH boundary for LLPS as a function of the $\mathrm{O}: \mathrm{C}$ of the organic particle: (a) particles containing one organic species, (b) particles containing two organic species, and (c) particles consisting of secondary organic material generated in environmental chambers. Only results for experiments with increasing $\mathrm{RH}$ are shown. Green circles represent the lower boundary for the LLPS, and red triangles represent the upper boundary for LLPS. Blue crosses indicate that LLPS was not observed during RH cycles. Uncertainties represent $2 \sigma$ of multiple measurements and the uncertainty from the calibration. Results for particles consisting of secondary organic material (c) were taken from Renbaum-Wolff et al. (2016), Rastak et al. (2017), and Song et al. (2017). The O : C range of the SOM particles is based on previous studies (Heaton et al., 2007; Lambe et al., 2015; Li et al., 2015; Renbaum-Wolff et al., 2016; Rastak et al., 2017; Song et al., 2017). The arrow at the top of the figure represents the $\mathrm{O}: \mathrm{C}$ range of organic particles in the atmosphere (Zhang et al., 2007; Hallquist et al., 2009; Jimenez et al., 2009; Heald et al., 2010; $\mathrm{Ng}$ et al., 2010).

ditional studies that can isolate these effects are needed to better understand LLPS in organic particles.

Data availability. Underlying material and related items for this paper are located in the Supplement.

The Supplement related to this article is available online at https://doi.org/10.5194/acp-18-12075-2018supplement. 
Author contributions. MS, SH, RJA, and YY conducted LLPS experiments. MS and AKB wrote the paper.

Competing interests. The authors declare that they have no conflict of interest.

Acknowledgements. This work was supported by the Natural Sciences and Engineering Research Council of Canada. Support from the National Research Foundation of Korea (NRF) grant funded by the Korea Government (MSIP) (2016R1C1B1009243) is also acknowledged.

Edited by: Ryan Sullivan

Reviewed by: two anonymous referees

\section{References}

Abbatt, J. P. D., Lee, A. K. Y., and Thornton, J. A.: Quantifying trace gas uptake to tropospheric aerosol: recent advances and remaining challenges, Chem. Soc. Rev., 41, 6555-6581, https://doi.org/10.1039/c2cs35052a, 2012.

Baltensperger, U., Dommen, J., Alfarra, R., Duplissy, J., Gaeggeler, K., Metzger, A., Facchini, M. C., Decesari, S., Finessi, E., Reinnig, C., Schott, M., Warnke, J., Hoffmann, T., Klatzer, B., Puxbaum, H., Geiser, M., Savi, M., Lang, D., Kalberer, M., and Geiser, T.: Combined determination of the chemical composition and of health effects of secondary organic aerosols: The POLYSOA project, J. Aerosol Med. Pulm. D, 21, 145-154, https://doi.org/10.1089/jamp.2007.0655, 2008.

Bertram, A. K., Martin, S. T., Hanna, S. J., Smith, M. L., Bodsworth, A., Chen, Q., Kuwata, M., Liu, A., You, Y., and Zorn, S. R.: Predicting the relative humidities of liquid-liquid phase separation, efflorescence, and deliquescence of mixed particles of ammonium sulfate, organic material, and water using the organic-to-sulfate mass ratio of the particle and the oxygen-tocarbon elemental ratio of the organic component, Atmos. Chem. Phys., 11, 10995-11006, https://doi.org/10.5194/acp-11-109952011, 2011.

Ciobanu, V. G., Marcolli, C., Krieger, U. K., Weers, U., and Peter, T.: Liquid-Liquid Phase Separation in Mixed Organic/Inorganic Aerosol Particles, J. Phys. Chem. A, 113, 10966-10978, https://doi.org/10.1021/Jp905054d, 2009.

Decesari, S., Fuzzi, S., Facchini, M. C., Mircea, M., Emblico, L., Cavalli, F., Maenhaut, W., Chi, X., Schkolnik, G., Falkovich, A., Rudich, Y., Claeys, M., Pashynska, V., Vas, G., Kourtchev, I., Vermeylen, R., Hoffer, A., Andreae, M. O., Tagliavini, E., Moretti, F., and Artaxo, P.: Characterization of the organic composition of aerosols from Rondônia, Brazil, during the LBA-SMOCC 2002 experiment and its representation through model compounds, Atmos. Chem. Phys., 6, 375-402, https://doi.org/10.5194/acp-6-375-2006, 2006.

Fard, M. M., Krieger, U. K., and Peter, T.: Short wave radiative impact of liquid-liquid phase separation in "Brown Carbon" aerosols, Atmos. Chem. Phys. Discuss., https://doi.org/10.5194/acp-2018-248, in review, 2018.
Freedman, M. A.: Phase separation in organic aerosol, Chem. Soc. Rev., 46, 7694-7705, https://doi.org/10.1039/c6cs00783j, 2017.

Ganbavale, G., Zuend, A., Marcolli, C., and Peter, T.: Improved AIOMFAC model parameterisation of the temperature dependence of activity coefficients for aqueous organic mixtures, Atmos. Chem. Phys., 15, 447-493, https://doi.org/10.5194/acp-15447-2015, 2015.

George, I. J. and Abbatt, J. P. D.: Heterogeneous oxidation of atmospheric aerosol particles by gas-phase radicals, Nat. Chem., 2, 713-722, https://doi.org/10.1038/nchem.806, 2010.

Gilardoni, S., Liu, S., Takahama, S., Russell, L. M., Allan, J. D., Steinbrecher, R., Jimenez, J. L., De Carlo, P. F., Dunlea, E. J., and Baumgardner, D.: Characterization of organic ambient aerosol during MIRAGE 2006 on three platforms, Atmos. Chem. Phys., 9, 5417-5432, https://doi.org/10.5194/acp-9-5417-2009, 2009.

Gorkowski, K., Beydoun, H., Aboff, M., Walker, J. S., Reid, J. P., and Sullivan, R. C.: Advanced aerosol optical tweezers chamber design to facilitate phase-separation and equilibration timescale experiments on complex droplets, Aerosol. Sci. Tech., 50, 13271341, https://doi.org/10.1080/02786826.2016.1224317, 2016.

Gorkowski, K., Donahue, N. M., and Sullivan, R. C.: Emulsified and Liquid Liquid Phase-Separated States of alphaPinene Secondary Organic Aerosol Determined Using Aerosol Optical Tweezers, Environ. Sci. Technol., 51, 12154-12163, https://doi.org/10.1021/acs.est.7b03250, 2017.

Hallquist, M., Wenger, J. C., Baltensperger, U., Rudich, Y., Simpson, D., Claeys, M., Dommen, J., Donahue, N. M., George, C., Goldstein, A. H., Hamilton, J. F., Herrmann, H., Hoffmann, T., Iinuma, Y., Jang, M., Jenkin, M. E., Jimenez, J. L., Kiendler-Scharr, A., Maenhaut, W., McFiggans, G., Mentel, Th. F., Monod, A., Prévôt, A. S. H., Seinfeld, J. H., Surratt, J. D., Szmigielski, R., and Wildt, J.: The formation, properties and impact of secondary organic aerosol: current and emerging issues, Atmos. Chem. Phys., 9, 5155-5236, https://doi.org/10.5194/acp9-5155-2009, 2009.

Hanel, G.: Single-Scattering Albedo of Atmospheric AerosolParticles as a Function of Relative Humidity, J. Atmos. Sci., 33, 1120-1124, https://doi.org/10.1175/15200469(1976)033<1120:Tssaoa>2.0.Co;2, 1976.

Heald, C. L., Kroll, J. H., Jimenez, J. L., Docherty, K. S., DeCarlo, P. F., Aiken, A. C., Chen, Q., Martin, S. T., Farmer, D. K., and Artaxo, P.: A simplified description of the evolution of organic aerosol composition in the atmosphere, Geophys. Res. Lett., 37, L08803, https://doi.org/10.1029/2010gl042737, 2010.

Heaton, K. J., Dreyfus, M. A., Wang, S., and Johnston, M. V.: Oligomers in the early stage of biogenic secondary organic aerosol formation and growth, Environ. Sci. Technol., 41, 6129_ 6136, https://doi.org/10.1021/es070314n, 2007.

Hodas, N., Zuend, A., Mui, W., Flagan, R. C., and Seinfeld, J. H.: Influence of particle-phase state on the hygroscopic behavior of mixed organic-inorganic aerosols, Atmos. Chem. Phys., 15, 5027-5045, https://doi.org/10.5194/acp-15-5027-2015, 2015.

Hodas, N., Zuend, A., Schilling, K., Berkemeier, T., Shiraiwa, M., Flagan, R. C., and Seinfeld, J. H.: Discontinuities in hygroscopic growth below and above water saturation for laboratory surrogates of oligomers in organic atmospheric aerosols, Atmos. Chem. Phys., 16, 12767-12792, https://doi.org/10.5194/acp-1612767-2016, 2016. 
Houle, F. A., Hinsberg, W. D., and Wilson, K. R.: Oxidation of a model alkane aerosol by $\mathrm{OH}$ radical: the emergent nature of reactive uptake, Phys. Chem. Chem. Phys., 17, 4412-4423, 2015.

IPCC: Climate Change 2013: The Physical Science Basis. Contribution of Working Group I to the Fifth Assessment Report of the Intergovernmental Panel on Climate Change, edited by: Stocker, T. F., Qin, D., Plattner, G.-K., Tignor, M., Allen, S. K., Boschung, J., Nauels, A., Xia, Y., Bex, V., and Midgley, P. M., Cambridge University Press, Cambridge, UK and New York, NY, USA, 1535, 2013.

Jang, Y., Kim, G., and Chiriboga, D. A.: Correlates of sense of control among older Korean-American immigrants: Financial status, physical health constraints, and environmental challenges, Int. J. Aging. Hum. Dev., 63, 173-186, https://doi.org/10.2190/9qmqTg4a-11dc-Cnrr, 2006

Jasper, J. J.: The surface tension of pure liquid compounds, J. Phys. Chem. Ref. Data, 1, 841-1009, https://doi.org/10.1063/1.3253106, 1972.

Jimenez, J. L., Canagaratna, M. R., Donahue, N. M., Prevot, A. S. H., Zhang, Q., Kroll, J. H., DeCarlo, P. F., Allan, J. D., Coe, H., Ng, N. L., Aiken, A. C., Docherty, K. S., Ulbrich, I. M., Grieshop, A. P., Robinson, A. L., Duplissy, J., Smith, J. D., Wilson, K. R., Lanz, V. A., Hueglin, C., Sun, Y. L., Tian, J., Laaksonen, A., Raatikainen, T., Rautiainen, J., Vaattovaara, P., Ehn, M., Kulmala, M., Tomlinson, J. M., Collins, D. R., Cubison, M. J., Dunlea, E. J., Huffman, J. A., Onasch, T. B., Alfarra, M. R., Williams, P. I., Bower, K., Kondo, Y., Schneider, J., Drewnick, F., Borrmann, S., Weimer, S., Demerjian, K., Salcedo, D., Cottrell, L., Griffin, R., Takami, A., Miyoshi, T., Hatakeyama, S., Shimono, A., Sun, J. Y., Zhang, Y. M., Dzepina, K., Kimmel, J. R., Sueper, D., Jayne, J. T., Herndon, S. C., Trimborn, A. M., Williams, L. R., Wood, E. C., Middlebrook, A. M., Kolb, C. E., Baltensperger, U., and Worsnop, D. R.: Evolution of Organic Aerosols in the Atmosphere, Science, 326, 1525-1529, https://doi.org/10.1126/science.1180353, 2009.

Kanakidou, M., Seinfeld, J. H., Pandis, S. N., Barnes, I., Dentener, F. J., Facchini, M. C., Van Dingenen, R., Ervens, B., Nenes, A., Nielsen, C. J., Swietlicki, E., Putaud, J. P., Balkanski, Y., Fuzzi, S., Horth, J., Moortgat, G. K., Winterhalter, R., Myhre, C. E. L., Tsigaridis, K., Vignati, E., Stephanou, E. G., and Wilson, J.: Organic aerosol and global climate modelling: a review, Atmos. Chem. Phys., 5, 1053-1123, https://doi.org/10.5194/acp-5-10532005, 2005.

Knopf, D. A., Alpert, P. A., and Wang, B. B.: The Role of Organic Aerosol in Atmospheric Ice Nucleation: A Review, ACS Earth Space Chem., 2, 168-202, 10.1021/acsearthspacechem.7b00120, 2018.

Krieger, U. K., Marcolli, C., and Reid, J. P.: Exploring the complexity of aerosol particle properties and processes using single particle techniques, Chem. Soc. Rev., 41, 6631-6662, https://doi.org/10.1039/c2cs35082c, 2012.

Kwamena, N. O. A., Buajarern, J., and Reid, J. P.: Equilibrium Morphology of Mixed Organic/Inorganic/Aqueous Aerosol Droplets: Investigating the Effect of Relative Humidity and Surfactants, J. Phys. Chem. A, 114, 5787-5795, https://doi.org/10.1021/Jp1003648, 2010.

Lambe, A. T., Chhabra, P. S., Onasch, T. B., Brune, W. H., Hunter, J. F., Kroll, J. H., Cummings, M. J., Brogan, J. F., Parmar, Y., Worsnop, D. R., Kolb, C. E., and Davidovits, P.: Effect of ox- idant concentration, exposure time, and seed particles on secondary organic aerosol chemical composition and yield, Atmos. Chem. Phys., 15, 3063-3075, https://doi.org/10.5194/acp15-3063-2015, 2015.

Li, Y. J., Lee, B. P., Su, L., Fung, J. C. H., and Chan, C. K.: Seasonal characteristics of fine particulate matter (PM) based on highresolution time-of-flight aerosol mass spectrometric (HR-ToFAMS) measurements at the HKUST Supersite in Hong Kong, Atmos. Chem. Phys., 15, 37-53, https://doi.org/10.5194/acp-1537-2015, 2015.

Losey, D. J., Parker, R. G., and Freedman, M. A.: pH Dependence of Liquid-Liquid Phase Separation in Organic Aerosol, J. Phys. Chem. Lett., 7, 3861-3865, https://doi.org/10.1021/acs.jpclett.6b01621, 2016.

Marcolli, C. and Krieger, U. K.: Phase changes during hygroscopic cycles of mixed organic/inorganic model systems of tropospheric aerosols, J. Phys. Chem. A, 110, 1881-1893, https://doi.org/10.1021/Jp0556759, 2006.

Martin, S. T.: Phase transitions of aqueous atmospheric particles, Chem. Rev., 100, 3403-3453, https://doi.org/10.1021/Cr990034t, 2000.

Ng, N. L., Canagaratna, M. R., Zhang, Q., Jimenez, J. L., Tian, J., Ulbrich, I. M., Kroll, J. H., Docherty, K. S., Chhabra, P. S., Bahreini, R., Murphy, S. M., Seinfeld, J. H., Hildebrandt, L., Donahue, N. M., DeCarlo, P. F., Lanz, V. A., Prévôt, A. S. H., Dinar, E., Rudich, Y., and Worsnop, D. R.: Organic aerosol components observed in Northern Hemispheric datasets from Aerosol Mass Spectrometry, Atmos. Chem. Phys., 10, 46254641, https://doi.org/10.5194/acp-10-4625-2010, 2010.

O’Brien, R. E., Wang, B. B., Kelly, S. T., Lundt, N., You, Y., Bertram, A. K., Leone, S. R., Laskin, A., and Gilles, M. K.: Liquid-Liquid Phase Separation in Aerosol Particles: Imaging at the Nanometer Scale, Environ. Sci. Technol., 49, 4995-5002, https://doi.org/10.1021/acs.est.5b00062, 2015.

Ovadnevaite, J., Zuend, A., Laaksonen, A., Sanchez, K. J., Roberts, G., Ceburnis, D., Decesari, S., Rinaldi, M., Hodas, N., Facchini, M. C., Seinfeld, J. H., and Dowd, C. O.: Surface tension prevails over solute effect in organic-influenced cloud droplet activation, Nature, 546, 637-641, https://doi.org/10.1038/nature22806, 2017.

Pankow, J. F.: Gas/particle partitioning of neutral and ionizing compounds to single and multi-phase aerosol particles. 1. Unified modeling framework, Atmos. Environ., 37, 3323-3333, https://doi.org/10.1016/S1352-2310(03)00346-7, 2003.

Pant, A., Parsons, M. T., and Bertram, A. K.: Crystallization of aqueous ammonium sulfate particles internally mixed with soot and kaolinite: Crystallization relative humidities and nucleation rates, J. Phys. Chem. A, 110, 8701-8709, https://doi.org/10.1021/Jp060985s, 2006.

Parsons, M. T., Mak, J., Lipetz, S. R., and Bertram, A. K.: Deliquescence of malonic, succinic, glutaric, and adipic acid particles, J. Geophys. Res.-Atmos., 109, D06212, https://doi.org/10.1029/2003jd004075, 2004.

Petters, M. D., Kreidenweis, S. M., Snider, J. R., Koehler, K. A., Wang, Q., Prenni, A. J., and Demott, P. J.: Cloud droplet activation of polymerized organic aerosol, Tellus B, 58, 196-205, https://doi.org/10.1111/j.1600-0889.2006.00181.x, 2006.

Rastak, N., Pajunoja, A., Navarro, J. C. A., Ma, J., Song, M., Partridge, D. G., Kirkevag, A., Leong, Y., Hu, W. W., Taylor, 
N. F., Lambe, A., Cerully, K., Bougiatioti, A., Liu, P., Krejci, R., Petaja, T., Percival, C., Davidovits, P., Worsnop, D. R., Ekman, A. M. L., Nenes, A., Martin, S., Jimenez, J. L., Collins, D. R., Topping, D. O., Bertram, A. K., Zuend, A., Virtanen, A., and Riipinen, I.: Microphysical explanation of the RH-dependent water affinity of biogenic organic aerosol and its importance for climate, Geophys. Res. Lett., 44, 5167-5177, https://doi.org/10.1002/2017g1073056, 2017.

Reed Harris, A. E., Pajunoja, A., Cazaunau, M., Gratien, A., Pangui, E., Monod, A., Griffith, E. C., Virtanen, A., Doussin, J. F., and Vaida, V.: Multiphase Photochemistry of Pyruvic Acid under Atmospheric Conditions, J. Phys. Chem. A, 121, 3327-3339, https://doi.org/10.1021/acs.jpca.7b01107, 2017.

Reid, J. P., Dennis-Smither, B. J., Kwamena, N. O. A., Miles, R. E. H., Hanford, K. L., and Homer, C. J.: The morphology of aerosol particles consisting of hydrophobic and hydrophilic phases: hydrocarbons, alcohols and fatty acids as the hydrophobic component, Phys. Chem. Chem. Phys., 13, 15559-15572, https://doi.org/10.1039/C1cp21510h, 2011.

Renbaum-Wolff, L., Song, M., Marcolli, C., Zhang, Y., Liu, P. F., Grayson, J. W., Geiger, F. M., Martin, S. T., and Bertram, A. K.: Observations and implications of liquid-liquid phase separation at high relative humidities in secondary organic material produced by a-pinene ozonolysis without inorganic salts, Atmos. Chem. Phys., 16, 7969-7979, https://doi.org/10.5194/acp16-7969-2016, 2016.

Schill, G. P. and Tolbert, M. A.: Heterogeneous ice nucleation on phase-separated organic-sulfate particles: effect of liquid vs. glassy coatings, Atmos. Chem. Phys., 13, 4681-4695, https://doi.org/10.5194/acp-13-4681-2013, 2013.

Shiraiwa, M., Ammann, M., Koop, T., and Pöschl, U.: Gas uptake and chemical aging of semisolid organic aerosol particles, P. Natl. Acad. Sci. USA, 108, 11003-11008, https://doi.org/10.1073/pnas.1103045108, 2011.

Shiraiwa, M., Zuend, A., Bertram, A. K., and Seinfeld, J. H.: Gasparticle partitioning of atmospheric aerosols: interplay of physical state, non-ideal mixing and morphology, Phys. Chem. Chem. Phys., 15, 11441-11453, https://doi.org/10.1039/C3cp51595h, 2013.

Smith, M. L., Bertram, A. K., and Martin, S. T.: Deliquescence, efflorescence, and phase miscibility of mixed particles of ammonium sulfate and isoprene-derived secondary organic material, Atmos. Chem. Phys., 12, 9613-9628, https://doi.org/10.5194/acp-12-9613-2012, 2012.

Song, M., Marcolli, C., Krieger, U. K., Zuend, A., and Peter, T.: Liquid-liquid phase separation and morphology of internally mixed dicarboxylic acids/ammonium sulfate/water particles, Atmos. Chem. Phys., 12, 2691-2712, https://doi.org/10.5194/acp12-2691-2012, 2012a.

Song, M., Marcolli, C., Krieger, U. K., Zuend, A., and Peter, T.: Liquid-liquid phase separation in aerosol particles: Dependence on $\mathrm{O}: \mathrm{C}$, organic functionalities, and compositional complexity, Geophys. Res. Lett., 39, L19801, https://doi.org/10.1029/2012g1052807, 2012b.
Song, M. J., Marcolli, C., Krieger, U. K., Lienhard, D. M., and Peter, T.: Morphologies of mixed organic/inorganic/aqueous aerosol droplets, Faraday Discuss., 165, 289-316, https://doi.org/10.1039/C3fd00049d, 2013.

Song, M., Liu, P., Martin, S. T., and Bertram, A. K.: Liquid-liquid phase separation in particles containing secondary organic material free of inorganic salts, Atmos. Chem. Phys., 17, 1126111271, https://doi.org/10.5194/acp-17-11261-2017, 2017.

Veghte, D. P., Altaf, M. B., and Freedman, M. A.: Size Dependence of the Structure of Organic Aerosol, J. Am. Chem. Soc., 135, 16046-16049, 10.1021/ja408903g, 2013.

Winston, P. W. and Bates, D. H.: Saturated Solutions for the Control of Humidity in Biological-Research, Ecology, 41, 232-237, https://doi.org/10.2307/1931961, 1960.

You, Y., Renbaum-Wolff, L., and Bertram, A. K.: Liquid-liquid phase separation in particles containing organics mixed with ammonium sulfate, ammonium bisulfate, ammonium nitrate or sodium chloride, Atmos. Chem. Phys., 13, 11723-11734, https://doi.org/10.5194/acp-13-11723-2013, 2013.

You, Y., Smith, M. L., Song, M. J., Martin, S. T., and Bertram, A. K.: Liquid-liquid phase separation in atmospherically relevant particles consisting of organic species and inorganic salts, Int. Rev. Phys. Chem., 33, 43-77, https://doi.org/10.1080/0144235X.2014.890786, 2014.

Zhang, Q., Jimenez, J. L., Canagaratna, M. R., Allan, J. D., Coe, H., Ulbrich, I., Alfarra, M. R., Takami, A., Middlebrook, A. M., Sun, Y. L., Dzepina, K., Dunlea, E., Docherty, K., DeCarlo, P. F., Salcedo, D., Onasch, T., Jayne, J. T., Miyoshi, T., Shimono, A., Hatakeyama, S., Takegawa, N., Kondo, Y., Schneider, J., Drewnick, F., Borrmann, S., Weimer, S., Demerjian, K., Williams, P., Bower, K., Bahreini, R., Cottrell, L., Griffin, R. J., Rautiainen, J., Sun, J. Y., Zhang, Y. M., and Worsnop, D. R.: Ubiquity and dominance of oxygenated species in organic aerosols in anthropogenically-influenced Northern Hemisphere midlatitudes, Geophys. Res. Lett., 34, L13801, https://doi.org/10.1029/2007gl029979, 2007.

Zuend, A. and Seinfeld, J. H.: Modeling the gas-particle partitioning of secondary organic aerosol: the importance of liquidliquid phase separation, Atmos. Chem. Phys., 12, 3857-3882, https://doi.org/10.5194/acp-12-3857-2012, 2012.

Zuend, A., Marcolli, C., Peter, T., and Seinfeld, J. H.: Computation of liquid-liquid equilibria and phase stabilities: implications for RH-dependent gas/particle partitioning of organicinorganic aerosols, Atmos. Chem. Phys., 10, 7795-7820, https://doi.org/10.5194/acp-10-7795-2010, 2010. 